\title{
Sønderjylland i dansk historisk forskning
}

\section{- træk af en udvikling}

\author{
af Henrik Becker-Christensen
}

Så sent som 75 år efter 1920 er Genforeningen ikke fuldbyrdet - i alt fald ikke hvad angår behandlingen af Sønderjylland i de Danmarkshistoriske værker. Ofte behandles landsdelen meget stedmoderligt $\mathrm{i}$ de store fremstillinger af Danmarks historie. På den baggrund skitserer direktør, dr. phil. Henrik Becker-Christensen, Aabenraa, udviklingen i studiet af Sønderjyllands historie siden 1840'erne. I dag er man nået så vidt, at landsdelen »kan selv« takket være en stærk udvikling $i$ de lokale forskningsinstitutioner.

I 1840 udkom C. F. Allens »Haandbog i Fædrelandets historie«. Den var resultatet af en prisopgave, som Selskabet for Efterslægten havde udsat nogle år tidligere. I forordet til bogen skrev forfatteren, at man længe havde savnet et skrift, der uden »... al for stor vidtløftighed og i et populært foredrag gav en skildring af Danmarks indre udvikling ved siden af en fremstilling af de ydre begivenheder «. Med disse ord havde Allen selv givet svaret på, hvorfor han vandt den udsatte pris. Hans værk ragede da også op over forgængernes og blev i kraft af de mange genudgivelser meget udbredt. Herved blev Allens Haandbog i Fædrelandets Historie med Kristian Erslevs ord »en hovedfaktor i det danske folks politiske opdragelse « i det 19. århundrede. ${ }^{1}$

Med til denne opdragelse hørte også interessen for Sønderjylland. Allerede i 1.udgaven fra 1840 havde C.F. Allen betonet, at Sønderjylland var en del af Danmark, som kun ved tidernes ugunst var kommet til at stå $i$ et løsere forhold til kongeriget. Omtalen af de sønderjyske forhold pegede således flere steder fremad ved at give læserne associationer til nutiden. Allen demonstrerede herved et vågent blik for de nationale problemer, der endnu var i deres vorden, da bogen blev skrevet $\mathrm{i}$ anden halvdel af 1830'erne.

Det fik betydning, da bogen i 1841 blev oversat til tysk og udgivet af en repræsentant fra den modsatte lejr. Det var professor Niels Nicolai Falck fra Kiels Universitet, der tidligt havde markeret sig som eksponent for en slesvigholstensk historieopfattelse og i den slesvigske stænderforsamling selv kom til at spille en aktiv rolle i det nationale opgør. Det bevirkede, at Falck uden Allens vidende strøg nogle passager om Sønderjyllands historie i den tyske udgave af Allens værk. 
Det blev påtalt af C. F. Allen i forordet til 2. udgaven af »Haandbog i Fædrelandets Historie«, der udkom i 1842. Allen var bl.a. utilfreds med, at Falck ved omtalen af Slesvigs inkorporation i 1721 havde strøget ordene om, at $\$ . .$. enhver $i$ hyldningen lovede for sig og sine efterkommere at være kongen tro og huld som eneste suveræn landsherre, ligesom også hans kongelige arveefterfølgere efter kongelovens lydende«. Tilsvarende var omtalen af, at det slesvigske våben havde fảet en mere fremtrædende placering i det danske rigsvåben "på grund af Slesvigs forandrede forhold til riget« forsvundet. Det samme gjaldt også et afsnit om det danske sprogs skæbne i Slesvig, som helt var udeladt i den tyske udgave. Sammenfattende skrev Allen: »Jeg kan ikke erkende etatsråd Falck berettiget til at foretage slige forandringer i en bog, på hvis titel mit navn dog er beholdt, forandringer, der er udgåede fra en anskuelse, som jeg er langt fra at dele, ligesom den er blevet bekæmpet af de mest ansete danske historikere og publicister $\aleph^{2}$

Denne forpostfægtning mellem C.F. Allen og N. N. Falck var et vidnesbyrd om den centrale placering, som Sønderjyllands historie fra starten havde i den nationale kamp mellem dansk og tysk. Begge parter søgte efter evne at hente ammunition til deres respektive standpunkter for og imod et Danmark til Ejderen og et Slesvig-Holsten til Kongeåen.

Da Sønderjylland »vågnede« i 1830'erne og 1840'erne - som det hedder i titlen på P. Lauridsens kendte værk - vågnede også interessen for Sønderjylland i dansk historieforskning. Det blev starten på en intensiv beskæftigelse med den politiske, statsretslige og sproglige udvikling. Senere spredte det sig også til kulturelle, sociale og økonomiske forhold, biografiske studier og meget andet.

Det er "Deutschland als Problem Dänemarks « - som Troels Fink har kaldt den tyske udgave af sin Sønderjyllandshistorie - der fra 1830'erne mere end noget andet stimulerede interessen for den sønderjyske historie. Brændstof har der været nok af. Det nationale opbrud, de slesvigske krige, afståelsen af Sønderjylland i 1864, fremmedherredømmet, Genforeningen i 1920, det tyske mindretals grænserevisionskrav, besættelsen, Sydslesvigrøret og udviklingen frem til København-Bonn erklæringerne i 1955 - for blot at nævne nogle af hovedoverskrifterne.

Tilgangen til Sønderjyllands historie har imidlertid været forskellig. I det meste af det 19.århundrede følte danske historikere sig kaldet til at påvise Danmarks statsretslige adkomst til hele Sønderjylland - og dermed et Danmark til Ejderen. Der blev her lagt vægt på betydningen af inkorporationen af den hertugelige del af Slesvig i 1721 og den dermed forbundne arvehyldning. Tilsvarende bestred man de tyske påstande om, at Slesvig og Holsten var »up ewig ungedeelt«, diskuterede augustenborgernes arveret og betonede landsde- 
Det historiske forskningsmiljo $i$ Sonderjylland barer $i$ hoj grad professor Troels Finks fingeraftryk. Fra 1963 var han med til at grundlagge danske forskningsinstitutter $i$ Aabenraa og Flensborg. De dér ansatte forskere gav ny naring til studiet af Sonderjyllands historie. Det betod en stark og professionel udvidelse af det lokale historiske arbejde, som tidligere mest var udfort af samatorer", som fritidsbeskaftigelse i ledige stunder. Foto: Dansk Centralbibliotek for Sydslesvig.

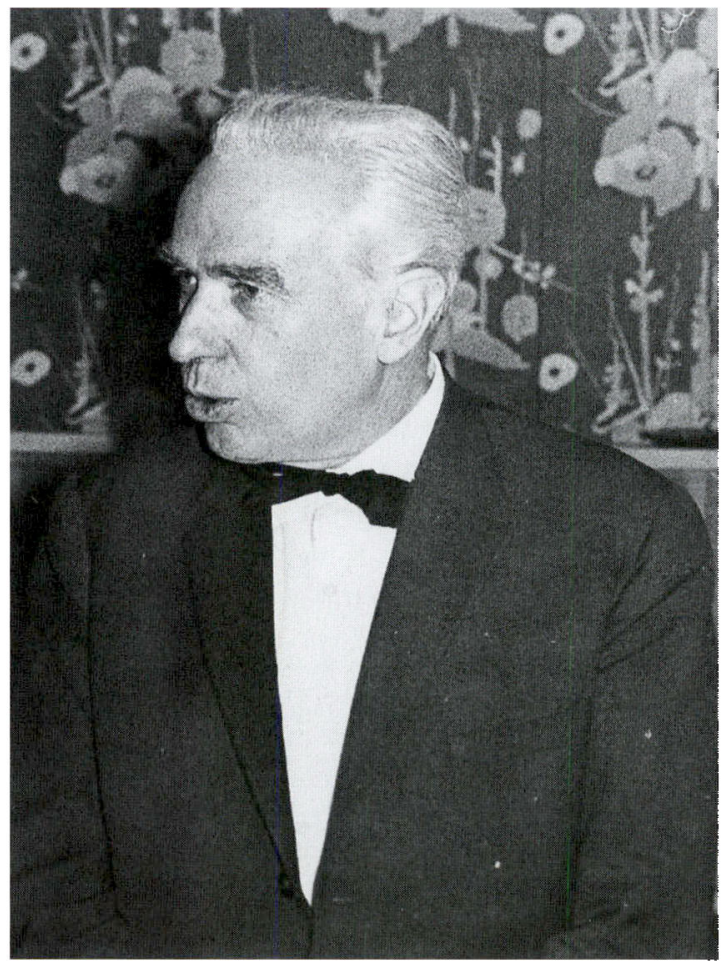

lens danske rod og særpræg. Samtidig blev alt tysk i reglen fremstillet i de mørkeste farver.

C. F. Allens sproglige studier er et godt eksempel på den grundholdning, der lå til grund for tilgangen til stoffet. I det bevægede år 1848 leverede han et bidrag »Om Sprog- og Folkeeiendommelighed i Hertugdømmet Slesvig eller Sønderjylland«. Det skulle med Allens ord bidrage til at "... gøre den overbevisning bestandig mere levende og almindelig, at vi har en fuldkommen god og retfærdig sag, og sjælden noget folk har været bedre i sin ret end Danmark i sin kamp for Slesvig ${ }^{3}$. Det gik igen i Allens afhandling om $»$ Det danske Sprogs Historie i Hertugdømmet Slesvig eller Sønderjylland« bd. I-II, der udkom 1857-58, og som var et af hans videnskabelige hovedværker.

Nederlaget i 1864 betød ikke nogen ændring - i første omgang. Det blev imidlertid en sønderjyde, historikeren A.D. Jørgensen - der senere også blev Danmarks første rigsarkivar, der i 1880'erne lagde grunden til et kursskifte. I sine »Fyrretyve Fortællinger af Fædrelandets Historie«, der udkom i 1882, udtrykte A. D. Jørgensen håbet om, at man i Sønderjylland engang kunne nå frem til en "national« grænsedragning. Herved forstod han en statsgrænse, 
der var draget der, hvor »... folket har sin grænse«. Det var et grundlæggende brud med de hidtidige fortalere for den "historiske ret«. Herved kom A. D. Jørgensen til at påvirke en ny generation af historikere i Danmark. Blandt dem var H.V.Clausen - ham med Clausen-linjen - Aage Friis, M. Mackeprang og Johan Ottosen, men flere fulgte efter. ${ }^{4}$ Den linje, der hermed var lagt, og som blev videreudviklet i demokratisk retning, har præget dansk historieopfattelse frem til i dag.

Den nationale linje i dansk historieskrivning skal således med Troels Finks ord forstås på baggrund af den dobbelte vision i det 19. århundrede, drømmen før 1864 om et Danmark til Ejderen og efter 1864 drømmen om det danske Danmark med grænsen draget, hvor sindelaget satte skel. Det gamle begrebsapparat var sejlivet, men den nye værdinorm vandt efterhånden frem. Det betød med Troels Finks formulering, at $"$... visionen om det danske Danmark blev det spejl, hvorfra strålerne kastedes tilbage i historien, og i lyset heraf blev nye problemstillinger ført frem. Det betød en forskydning i vurderingsgrundlaget, men således at »rigsbegrebet« ikke fuldstændig blev skudt til side for »folkebegrebet«. Den nationale linje i dansk historieforskning er kendetegnet af begge begreber, men således at folket stadig stærkere har fået første prioritet ${ }^{5}$

Studiet af Sønderjyllands historie har i tidens løb kaldt på mange kræfter over hele landet. I mange år var København med sit universitet, rigsarkiv og øvrige akademiske verden arnested for de mest dybtgående og mest omfattende studier af den sønderjyske historie. Eksempler herpå er Erik Erslevs afhandlinger om »Erik af Pommern, hans kamp for Sønderjylland og Kalmarunionens opløsning«, »Frederik IV og Slesvig" og "Augustenborgernes arvekrav«, samt Aage Friis' bredt anlagte storværk »Den danske Regering og Nordslesvigs Genforening med Danmark« bd. I-IV. Blandt de mange navne kan for en senere tid nævnes Vilhelm la Cour, Holger Hjelholt, Johan Hvidtfeldt og Harald Jørgensen. Det københavnske engagement er imidlertid blevet gradvist mindre i tiden efter 1945, hvor tyngdepunktet i den sønderjyske forskning blev forskudt fra øst mod vest.

I 1942 var der blevet oprettet et lektorat i Sønderjyllands historie ved Aarhus Universitet. Hermed blev spiren lagt til et nyt kraftcenter. I 1946 blev lektoratet omdannet til et docentur og i 1950 til et professorat med samme faglige forpligtelse. Det var Troels Fink, der med de nævnte titler sikrede det videnskabelige indhold og lagde grunden til en sønderjysk forskningstradition i Århus, der kom til at præge flere af hans elever. Efter at Fink i 1959 var blevet dansk generalkonsul i Flensborg, blev det sønderjyske engagement i Århus videreført af bl.a. Gottlieb Japsen, Lorenz Rerup, H. P.Clausen, Johan Peter Noack og Jørgen Elklit. 


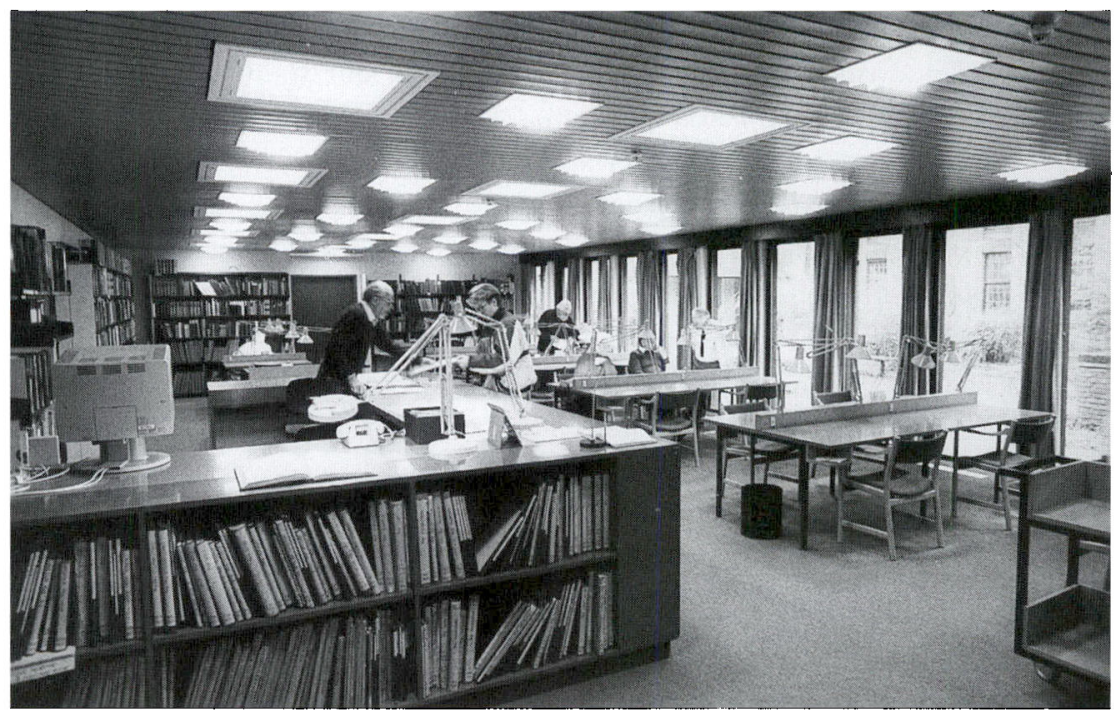

Siden oprettelsen $i 1933$ har landsarkivet $i$ Aabenraa stået $i$ centrum for arbejdet med Sonderjyllands historie. I 1976 fik landsarkivets arkivarer ligesom andre videnskabeligt ansatte på Kulturministeriets institutioner officielt krav på at kunne forske $i 2 / 7$ af deres arbejdstid. Det gav ny vagt til institutionens rolle $i$ det lokale historiske arbejde. Resultaterne af arkivarernes og andre forskeres arbejde med landsarkivets samlinger er ofte udgivet i et samarbejde med Historisk Samfund for Sonderjylland. Landsarkivets lasesal er her fotograferet af Tage Ludvigsen i 1989.

Som følge af pensionering eller anden beskæftigelse begyndte det fra midten af 1970'erne at tynde ud i rækkerne i Århus. Siden da har det i geografisk henseende været forskningens genstand - Sønderjylland, der $i$ institutionel henseende har været sæde for den mest omfattende udforskning af landsdelens historie.

Grunden hertil blev lagt i 1933 ved oprettelsen af Landsarkivet for de Sønderjyske Landsdele i Aabenraa. Det gav den i Sønderjylland baserede historieskrivning et afgørende løft - dels ved den nemme adgang til de skriftlige kilder, dels ved den forskning, som arkivets medarbejdere selv stod for, og endelig ikke mindst ved den frugtbringende alliance, som blev skabt mellem landsarkivet og det i 1922 oprettede Historisk Samfund for Sønderjylland.

Centrale skikkelser i disse bestræbelser var de skiftende landsarkivarer Frode Gribsvad, Peter Kristian Iversen og Hans H. Worsøe, hvor de to sidstnævnte begge blandt mange andre gøremål har aftjent en længere værnepligt som formænd for Historisk Samfund for Sønderjylland. Den nære forbindelse mellem landsarkivet og Historisk Samfund for Sønderjylland har virket stærkt stimulerende på såvel det lokalhistoriske arbejde som den forskningsbaserede interesse for landsdelens historie. Det har i årenes løb resulteret i en lang række 
bøger og utallige afhandlinger i de to tidsskrifter Sønderjyske Årbøger og Sønderjysk Månedsskrift. Landsarkivet har haft - og har stadig - en afgørende betydning for udforskningen af Sønderjyllands historie. De mange hyldemeter med arkivalier gør det til et uvurderligt værksted for den historiske forskning og en læreplads for nye historikere. To af svendene i dette værksted - Peter Kristian Iversen og Hans $\mathbf{H}$. Worsøe - blev selv mestre. Det samme gjaldt også Johan Hvidtfeldt, der senere blev landsarkivar i Viborg og rigsarkivar i København, samt Dorrit Andersen, der i dag er landsarkivar i Odense. Af andre svende, der siden er blevet selvstændige, kan nævnes Jørgen Witte og Lars N. Henningsen, mens Hans Schultz Hansen og Bjørn Poulsen i dag gør god fyldest som arkivarer. Alle har de været med til at styrke forskningen $i$ Sønderjylland og forankre landsarkivets centrale position.

Hertil kommer den forskning, som medarbejderne ved de sønderjyske museer og seminarier har lagt ryg til i tiden efter 1920. Nævnes her skal museumsverdenens grand old men Hans Neumann, Jørgen Slettebo og Sigurd Schoubye, der hver på deres felt har været med til at styrke interessen for Sønderjyllands historie og ydet bidrag til kendskabet hertil. Det samme gælder deres "Nachwuchs« i skikkelse af bl.a. Inge Adriansen, Steen W. Andersen og Stine Wiell. Inden for seminarieverdenen er der absolut grund til at nævne den store forskningsindsats, som studielektor H.V.Gregersen, Haderslev, har ydet gennem et langt liv, og som har resulteret $i$ talrige bøger og afhandlinger om Sønderjyllands historie. Hertil kommer flere andre, der som enkeltpersoner har markeret sig i en forskningsmæssig sammenhæng. Eksempler herpå er Anders Ture Lindstrøm og Bjørn Svensson, samt de hjemmetyske akademikere Immo Doege og Günter Weitling. Flere andre kan nævnes, men det vil føre for vidt.

Med Troels Finks tilbagevenden i 1959 blev Flensborg et nyt »stronghold« for dansk historisk forskning. Samtidig blev der sat nye initiativer i gang. En frugt heraf var oprettelsen af Studieafdelingen ved det danske centralbibliotek i Flensborg, der har til formål særlig at beskæftige sig med Sydslesvigs historie. Det har ført til adskillige vægtige afhandlinger, hvoraf flere er blevet antaget som disputatser. Studieafdelingens mangeårige leder Johann Runge har spillet en central rolle i dette arbejde.

I 1976 lykkedes det endvidere Troels Fink med økonomisk støtte fra Sønderjyllands Amt og staten at oprette Institut for grænseregionsforskning i Aabenraa. Det var en gammel drøm om at skabe et sønderjysk forskningsinstitut der her gik i opfyldelse, men nu tilpasset en ny tids behov. Som instituttets første direktør stod Fink selv for udgivelsen af sit store værk »Da Sønderjylland blev delt 1918-1920«, bd. I-III. Det er på instituttet senere fulgt op af vægtige afhandlinger ved Johan Peter Noack og Henrik Becker-Christensen 


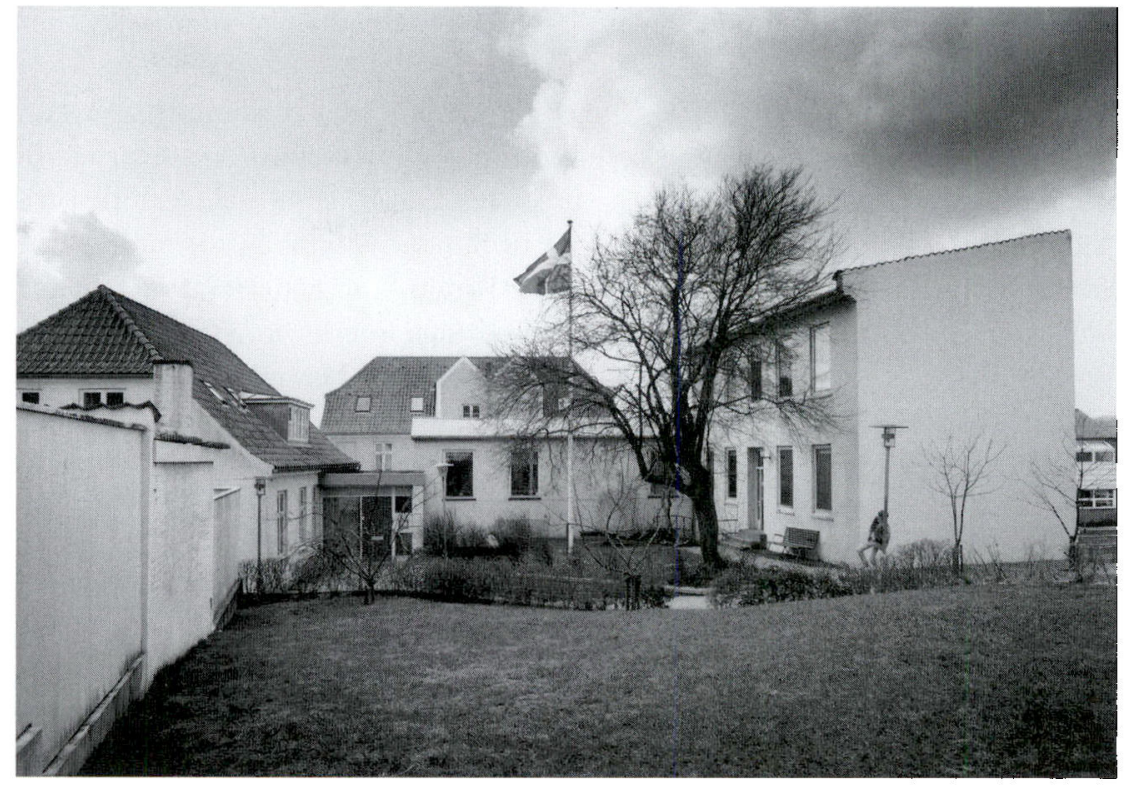

Institut for Granseregionsforskning blev oprettet $i$ 1976. Det har til formal at drive forskning inden for samfundsvidenskabelige og humanistiske problemstillinger - fortrinsvis $i$ emner af betydning for den dansk-tyske granseregion. Det har bl.a. fort til udgivelse af talrige boger om Sonderjyllands deling 1918-1920, det danske og det tyske mindretals historie, by-og sognehistorier, enkeltinstitutioners og virksomheders historie og Harvejens historie. Instituttet har til huse i Persillegade $i$ Aabenraa og beskaftiger i 199512 videnskabelige medarbejdere - heraf tre historikere.

Foto i Institut for Granseregionsforskning.

om det danske og det tyske mindretals historie, der begge blev antaget som disputatser. Hertil kommer flere andre udgivelser - bl.a. ved Christian Kaatmann og Carsten Porskrog Rasmussen.

I 1985 kom der i institutionel henseende et nyt skud på stammen, da det $\mathrm{i}$ 1962 oprettede Historiske samlinger for Sønderjylland med økonomisk støtte fra Sønderjyllands Amt blev omdannet til Institut for Sønderjysk Lokalhistorie med den meget kyndige Henrik Fangel som leder. Det betød ikke kun en styrkelse af det lokalhistoriske arbejde, men også skabelsen af en ny platform for forskning i landsdelens historie. Det samme var tilfældet da Dansk Centralbibliotek i Flensborg få år senere i 1989 barslede med et arkiv for danskheden i Sydslesvig under ledelse af Lars N. Henningsen. På det seneste er den historiske ekspertise i grænselandet også blevet styrket ved professor Lorenz Rerups tilbagevenden til Flensborg, hvor han i 1994 overtog posten som dansk generalkonsul. Alt i alt må det således konstateres - uden at forklej- 
ne den indsats der ydes andre steder - at Sønderjylland $\mathrm{i}$ dag »kan selv«, når det gælder forskning i landsdelens historie.

Målt med den store alen, er der ingen anden landsdel i Danmark, der kan opvise en så omfattende historisk litteratur. Et fysisk udtryk herfor er B. Erichsen og A. Krarups »Dansk Historisk Bibliografi«, der dækker tiden fra 1831 til 1912. Her fylder henvisningerne til Sønderjyllands historie mere end 200 sider. Det samme er tilfældet i Henry Bruuns fortsættelse af værket for tiden 1913-1943! En tilsvarende overskuelig, men stærkt forenklet målestok for den historiske interesse frem til i dag findes ikke. Der er imidlertid ingen tvivl om, at stakken af bøger og artikler er vokset betydeligt i de sidste 50 år. Som et eksempel på den seneste udvikling kan det nævnes, at Det sønderjyske landsbibliotek i Aabenraa alene i årene fra 1989 til første halvdel af 1995 har registreret en nytilgang af bøger om Sønderjyllands historie på 76 stk. Hertil kommer så den store mængde af artikler om landsdelens historie, der mangedobler det næunte antal bogtitler fra de seneste år. Sagt med andre ord, er den mængde af historisk litteratur om Sønderjylland, der er blevet produceret i tiden efter 1830, aldeles overvældende.

Hvis man i dag 75 år efter Nordslesvigs genforening med det gamle land, gør status over Sønderjyllands placering i dansk historisk forskning, er der dog et område, hvor landsdelen stadig er stedbarn. Det gælder omtalen af Sønderjylland i de store Danmarkshistoriske værker. Her er skellet ved Kongeåen blevet opretholdt selv i de allernyeste mammutværker fra Gyldendals og Politikens forlag. Det efterlader det mere principielle spørgsmål, hvem historikerne skriver Danmarkshistorie for, og hvordan man i geografisk henseende skal afgrænse sin fremstilling.

Sønderjylland har det billedligt talt med at gå ud og ind af Danmarkshistorien afhængig af, hvilken periode den enkelte forfatter beskæftiger sig med. Ingen vil anfægte, at Sønderjylland i vikingetid og middelalder spiller en stor rolle for forståelsen af den politiske udvikling i det øvrige Danmark og dermed indtager en tilsvarende placering i fremstillingerne. Det samme gør sig uden diskussion gældende $\mathrm{i}$ bind om det 19. og 20. århundredes Danmarkshistorie. I en overordnet sammenhæeng er det derfor utilfredsstillende, at den mellemliggende periode - det vil sige fra udgangen af middelalderen og frem til 1830 ofte bliver så stedmoderligt behandlet, da læseren herved taber tråden i værket og ikke har de rette forudsætninger for at forstå omtalen af tiden efter 1830 . Hertil kommer, at en moderne skildring af Danmarks historie gerne skulle henvende sig til alle danske læsere, hvoraf en del som bekendt bor syd for Kongeåen.

Problemet kan for den "mellemliggende periode" - tiden fra slutningen af middelalderen og frem til 1830 - løses ved at indføje særlige, mere udførlige 
kapitler om Sønderjylland, der omhandler de punkter, hvor forholdene i hertugdømmet adskilte sig fra kongeriget, og hvor der gøres rede for, hvad der forbandt de to områder. Derimod kan andre forhold, som er fælles for hertugdømmet og kongeriget, udmærket inddrages i den øvrige fremstilling.

Spørgsmålet om den geografiske afgrænsning af et Danmarkshistorisk værk er centralt, men man skal næppe vente enighed herom. Holdningerne vil være forskellige - bl.a. afhængigt af, om problemet anskues fra København eller Sønderjylland. Man kan her let få den kætterske tanke, at det er ukendskab eller manglende lyst til at sætte sig ind i de sønderjyske forhold, der undertiden har fået historikere $\mathrm{i}$ »det gamle land" til at vige tilbage for at beskæftige sig med forholdene syd for Kongeåen. Der er imidlertid også eksempler på, at historikere med dødsforagt har kastet sig over Sønderjyllands historie og på tryk har demonstreret deres ukendskab hertil - selv i vægtige værker til universitetsbrug.

Det gælder f.eks. det af Gyldendal i 1988 udgivne bd. 7 af værket "Danmarks Historie« for tiden 1914-1945. Her kan man bl.a. på side 234 læse om det danske og det tyske mindretal at de »... i 1920'erne [var] omtrent lige store (det danske var dog størst) ca. 10.000 på hver side ...«. Det er - for at sige det lige ud - rent sludder. Det tyske mindretal i Nordslesvig bestod af 30-35.000 personer og var dermed langt større end det danske mindretal i Sydslesvig. Af samme skuffe er oplysningen i nævnte værk side 235, at »Forsøget fra dansk side på at få en dansk-tysk mindretalstraktat strandede dog.« Det forholdt sig lige modsat! Det var Danmark der i 1920'erne - ligesom før og siden - ikke ville indgå en mindretalstraktat med Tyskland.

Man kan altså, for at vende tilbage til udgangspunktet, med hensyn til spørgsmålet om den geografiske afgrænsning af de Danmarkshistoriske værker med en vis ret hævde, at på dette område er Genforeningen endnu ikke blevet fuldbyrdet 75 år efter 1920. Dette forhold blev da også taget op i en større sammenhæng på Statens Humanistiske Forskningsråds seminar den 2. november 1993 i København om »Dansk historieforskning gennem de sidste 25 år, nu og i år 2012«.

Her var fil. dr. Harald Gustavsson fra Lunds Universitet blevet bedt om at komme med et indlæg om »Dansk historieforskning set udefra«. Som den lille dreng i »kejserens nye klæder« kritiserede han dansk historieforskning for, at den $\mathrm{i}$ fremstillinger om tiden før 1864 havde koncentreret sig om det, han kaldte for »lille Danmark « - dvs. kongeriget bestående af Nørrejylland, Fyn og Sjælland m.m. Derimod havde man glemt at inddrage de andre rigsdele i form af Norge, Island, Grønland, Færøerne og hertugdømmerne i den samlede fremstilling. Herved var væsentlige komparative perspektiver gået tabt, som ikke blev opvejet af, at der var lavet særskilte værker om hvert af disse 
områder. I stedet burde de inddrages som en naturlig del af den samlede fremstilling. Hvis man ikke gør det, går det ifølge Harald Gustavsson ud over forståelsen af udviklingen og dermed også af Danmarks forhold til omverdenen.

Det er set i denne sammenhæng, at Sønderjyllands historie kan være med til at give Danmarkshistorien et bredere perspektiv og må inddrages heri på lige fod med andre rigsdele. I den henseende mangler der endnu - for at citere C.F. Allens ord fra indledningen af denne artikel - et værk, der uden $" . .$. al for stor vidtløftighed og $i$ et populært foredrag giver en skildring af Danmarks indre udvikling ved siden af en fremstilling af de ydre begivenheder $\%$.

\section{NOTER}

1. Kr. Erslevs her citerede udsagn findes i omtalen af C. F. Allen i Salmonsens Konversations Leksikon bd. I pp. 538-539.

2. Forord til 2. udgave af »Haandbog i Fxdrelandets Historie $\AA$ (1842).

3. Brev fra C.F.Allen til F.S. Bang 11.1.1849, citeret efter Dansk Biografisk leksikon, artikel om C.F. Allen.

4. Se nærmere herom i Lorens Rerups artikel om A. D. Jørgensen i Dansk Biografisk Leksikon.

5. Linier i dansk historieskrivning i nyere tid, pp. 77-79 (1976). 